Advances in X-ray Analysis Volumes 1- 39 (1957 - 1995)

Volume 20. Twenty-fifth Annual Conference on Applications of X-ray Analysis, August 4-6, 1976 
CONTENTS

FOREWORD.

PREFACE • • • • • • • • • • • • • • • • • • • . vii

X-RAY POWDER DIFFRACTION

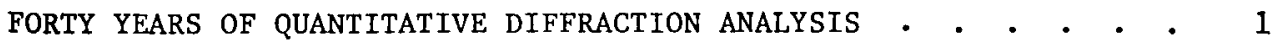

L. E. Alexander

QUANTITATIVE MATCHING OF POWDER DIFFRACTION PATTERNS • • • • 15

L. K. Freve1

EXPERIMENTAL AND CALCULATED STANDARDS FOR QUANTITATIVE

ANALYSIS BY POWDER DIFFRACTION.

C. R. Hubbard and D. K. Smith

X-RAY DIFFRACTION EXAMINATION OF THE PHASES IN EXPANSIVE

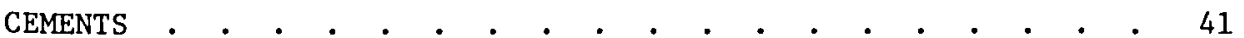

K. Mather

THE SINGLE CRYSTAL VS. THE POWDER METHOD FOR IDENTIFICATION

OF CRYSTALLINE MATERIALS. • • • • • • • • • • • • . 53

A. D. Mighe11

PHASE IDENTIFICATION BY X-RAY POWDER DIFFRACTION.

EVALUATION OF VARIOUS TECHNIQUES . . . . . . . . . . . . 63

J. D. Hanawalt

CHEMICAL IDENTIFICATION AND PHASE ANALYSIS OF TRANSPLUTONIUM

ELEMENTS AND COMPOUNDS VIA X-RAY POWDER DIFFRACTION. • • • . 75

J. R. Peterson

X-RAY DIFFRACTION EXAMINATION OF COAL COMBUSTION PRODUCTS RELATED

TO BOILER TUBE FOULING AND SLAGGING • • • • • • • . • . 85

M. H. Mazza and J. S. Wilson

COMPUTER IDENTIFICATION TECHNIQUES FOR CRYSTALLINE COMPOUNDS

USING THE JCPDS POWDER DIFFRACTION FILE AS A DATA

REFERENCE. • • • • • • . . • • • • • • • •

COMPUTER SEARCHING OF THE JCPDS POWDER DIFFRACTION FILE • . • 113

P. F. Dismore 
A ROUND ROBIN TEST TO EVALUATE COMPUTER SEARCH/MATCH METHODS FOR QUALITATIVE POWDER DIFFRACTOMETRY. • • • • • . 125

R. Jenkins

DIRECT QUANTITATIVE DETERMINATION OF SILICA BY X-RAY DIFFRACTION

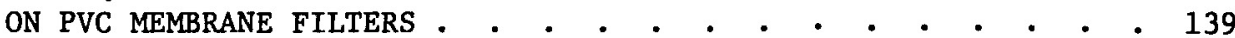

W. W. Henslee and R. E. Guerra

INTERNAL STANDARD AND DILUTION ANALYSES APPLIED TO THE

KINETICS OF TIB FORMATION . . . . . . . . . . . . . 153

G. C. Walther and R. W. Gould

THE EFFECT OF THE $K$ DOUBLET DIFFRACTED PEAK POSITION ON

THE PRECISION OF THE LATTICE CONSTANT . • • . • • . • . 161

C. P. Gazzara

ENERGY DISPERSIVE X-RAY DIFFRACTOMETRY. • . • • • • • • 171

M. Mantler and W. Parrish

A NEW METHOD FOR THE DETERMINATION OF THE TEXTURE OF

MATERIALS OF CUBIC STRUCTURE FROM INCOMPLETE REFLECTION

POLE FIGURES. . • • • • • • • • • • • • • • • . 187

D. Ruer and R. Baro

X-RAY TOPOGRAPHY

CRYSTAL SUBGRAIN MISORIENTATIONS VIA X-RAY DIFFRACTION

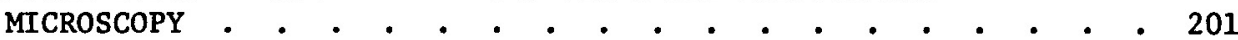

R. W. Armstrong, C. Cm. Wu, and E. N. Farabaugh

SOME TOPOGRAPHIC OBSERVATIONS OF THE EFFECTS OF DYNAMICAL

DIFFRACTION IN IMPERFECT METAL CRYSTALS. . . . . . . . . 207

W. J. Boettinger, H. E. Burdette, E. N. Farabaugh, and

M. Kuriyama

DIRECT DISPLAY OF X-RAY TOPOGRAPHIC IMAGES - • • • • • • 221

R. E. Green, Jr.

CHARACTERIZATION OF STRAIN DISTRIBUTION AND ANNEALING

RESPONSE IN DEFORMED SILICON CRYSTALS . • • • • • • • . 237

S. Weissmann and T. Saka

CRYSTAL IMPERFECTIONS AND MAGNETIC DOMAIN WALLS IN

THICK CZOCHRALSKI-GROWN NICKEL SINGLE CRYSTALS • • • • • • 245

M. Kuriyama, W. J. Boettinger and H. E. Burdette

\section{X-RAY DIFFRACTION STRESS ANALYSIS}

SOME PROBLEMS IN X-RAY STRESS MEASUREMENTS . • • • • • • • . 259

B. D. Cullity

STRESS MEASUREMENTS IN THIN FILMS DEPOSITED ON SINGLE CRYSTAL SUBSTRATES THROUGH X-RAY TOPOGRAPHY TECHNIQUES. • • . 273

E. W. Hearn 
LOCATION OF DIFFRACTOMETER PROFILES IN X-RAY STRESS

ANALYSIS. • • • • • • • • • • • • • • • • • . 283

D. Kirk and P. B. Caulfield

STUDY OF THE PRECISION OF X-RAY STRESS ANALYSIS

M. R. James and J. B. Cohen

THE EFFECT OF TEMPERATURE AND LOAD CYCLING ON THE RELAXATION

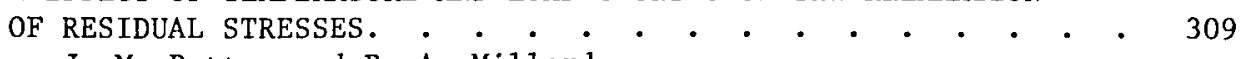

J. M. Potter and R. A. Millard

STRESS MEASUREMENTS ON COLD-WORKED FASTENER HOLDS. . • • . 321

G. Dietrich and J. M. Potter

DIFFRACTION TECHNIQUE FOR STRESS MEASUREMENT IN POLYMERIC

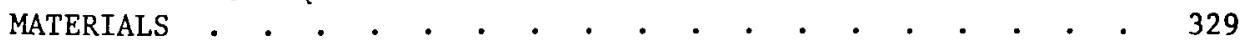

C. S. Barrett

X-RAY DIFFRACTION STUDIES OF SHOCKED LUNAR ANALOGS

R. E.Hanss, B. R. Montague, and C. P. Galindo

A METHOD OF DETERMINING THE ELASTIC PROPERTIES OF ALLOYS

IN SELECTED CRYSTALLOGRAPHIC DIRECTIONS FOR X-RAY

DIFFRACTION RESIDUAL STRESS MEASUREMENT

P. S. Prevey

THE NEED FOR EXPERIMENTALLY DETERMINED X-RAY ELASTIC

CONSTANTS

R. H. Marion and $\dot{J}$. $\dot{B}$. Cohen

A MODIFIED DIFFRACTOMETER FOR X-RAY STRESS MEASUREMENTS

E. Macherauch and $U$. Wolfstieg

A DUAL DETECTOR DIFFRACTOMETER FOR MEASUREMENT OF RESIDUAL STRESS

C. M. Mitche 11

X-RAY RESIDUAL STRESS MEASUREMENTS USING PARALLEL BEAM OPTICS. • 393 R. M. Chrenko

X-RAY FLUORESCENCE

PROTON-INDUCED X-RAY EMISSION ANALYSIS OF HUMAN AUTOPSY TISSUES . . . . . . 403

R. D. Lear, H. A. Van Rinsvelt, and W. R. Adams

POLYMER FILMS AS CALIBRATION STANDARDS FOR X-RAY FLUORESCENCE

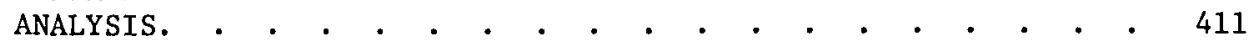

T. G. Dzubay, P. J. Lamothe and H. Yasuda

CHEMICAL ANALYSIS OF NICKEL ORES BY ENERGY DISPERSIVE X-RAY FLUORESCENCE

B. D. Wheeler, D. M. Bartell and J. A. Cooper 
DETERMINATION OF SULFUR, ASH, AND TRACE ELEMENT CONTENT OF COAL, COKE, AND FLY ASH USING MULTIELEMENT TUBE-EXCITED

X-RAY FLUORESCENCE ANALYSIS. . . . . . . . . . J. A. Cooper, B. D. Wheeler, G. J. Wolfe, D. M. Bartell, 431 and D. B. Schlafke

ADVANCES IN THE PRECONCENTRATION OF DISSOLVED IONS IN WATER SAMPLES D. E. Leyden

CONCENTRATION OF $\mathrm{U}$ AND NP FROM Pu AND Pu ALLOYS FOR DETERMINATION BY X-RAY FLUORESCENCE.

J. M. Hanse1, Jr., C. J. Marte11, G. B. Ne1son, and E. A. Hakkila

PRECONCENTRATION OF URANIUM IN NATURAL WATERS FOR X-RAY FLUORESCENCE ANALYSIS. L. R. Hathaway and G. W. James

"LOSS ON IGNTTION" IN FUSED GLASS BUTTONS.

R. LeHoullier, S. Turmel, and F. Claisse

MEASUREMENT OF "CHEMICAL SHIFT" BY AN AUTOMATED COMMERCIAL X-RAY FLUORESCENCE SPECTROMETER

L. G. Dowe11, J. M. Bennett, and D. E. Passoja

LOW ENERGY MASS ABSORPTION COEFFICIENTS FROM PROTON INDUCED X-RAY SPECTROSCOPY . • . • • • • • • • • . . 481

A. Lurio, W. Reuter and J. Keller

PROCESSING OF ENERGY DISPERSIVE X-RAY' SPECTRA J. C. Russ

USE OF X-RAY SCATTERING IN ABSORPTION CORRECTIONS FOR X-RAY FLUORESCENCE ANALYSIS OF AEROSOL LOADED FILTERS

K. K. Nielson and S. R. Garcia

AN INTERACTIVE PROGRAM FOR THE CONTROL OF THE X-RAY SPECTROMETER, FOR DATA COLLECTION AND DATA MANIPULATION - USE IN QUALITATIVE ANALYSIS .

R. Jenkins, D. Myers and F. R. Paolini

LAMA I - A GENERAL FORTRAN PROGRAM FOR QUANTITATIVE X-RAY FLUORESCENCE ANALYSIS. D. Laguitton and M. Mantler

\section{$\mathrm{X}$-RAY INSTRUMENTATION}

A NOVEL X-RAY POWDER DIFFRACTOMETER DETECTOR SYSTEM 529

S. K. Byram, B. Han, G. B. Rothbart, R. N. Samdah1, and R. A. Sparks

COUNTING RATE PERFORMANCE OF PULSED-TUBE SYSTEMS

A. O. Sandborg and J. C. Russ 
A NEW METHOD FOR THE ELIMINATION OF THE WALL EFFECT IN PROPORTIONAL COUNTER.

H. Sipily and E. Kiuru

X-RAY INTENSITIES FROM COPPER-TARGET DIFFRACTION TUBES . • • • 565

M. A. Short

POLARIZED RADIATION PRODUCED BY SCATTER FOR ENERGY

DISPERSIVE X-RAY FLUORESCENCE TRACE ANALYSIS. • • • • • . 575

R. W. Ryon

AUTHOR INDEX • • • • • • • • • • • • • • • • • . 591

SUBJECT INDEX. • • • • • • • • • • • • • • • • 593 